\author{
Lukasz Karol BUGOWSKI, PhD \\ Faculty of Economics and Finance, University of Bialystok \\ e-mail: l.bugowski@uwb.edu.pl \\ ORCID: 0000-0002-8347-0723
}

DOI: $10.15290 /$ oes.2019.04.98.06

\title{
ETHNIC DIVERSITY AND SOCIAL CAPITAL OF THE PODLASKIE VOIVODESHIP
}

\begin{abstract}
Summary
Purpose - An assessment of the level of social capital in the context of ethnic diversity using the example of the Podlaskie voivodeship. Furthermore, showing the relationship between social capital and local and regional development.

Research method - Quantitative and comparative analyses of selected indicators of the surveyed territorial units (powiats of the Podlaskie Voivodeship) while maintaining the criterion of ethnic diversity. Data from the Central Statistical Office (Local Data Bank) and the National Electoral Commission for the period 2010-2018 were used.

Results - The level of social capital is higher in multi-ethnic powiats, in particular as far as the civic dimension is concerned, which is measured by the use of passive and active voting rights. Similarly, the number of foundations, associations and social organizations per 1,000 inhabitants is higher in multiethnic powiats. As far as the level of entrepreneurship is concerned, the majority of powiats of diversified nationalities is insignificant, while single-nation powiats have higher rates in relation to membership in sports clubs.

Originality / value / implications / recommendations - A thesis which is popular in the subject literature that ethnically diverse areas are characterized by lower social capital is not true in the case of the Podlaskie voivodeship, in which ethnic groups have been present for centuries. Consequently, it may be assumed that ethnic diversity has a negative impact on the level of social capital only temporarily.
\end{abstract}

Key words: social capital, ethnic diversity, regional development

JEL Classification: A13, R11, Z13

\section{Introduction}

Social capital has been the subject of research since the second half of the $20^{\text {th }}$ century. Initially, the issues related to social networks were in the centre of interests of sociologists, but concurrently to the increased importance of endogenous developmental factors, social capital has become an area studied also by economists, in particularly in the context of the regional and local development. It was observed

1 Article received on 2 August 2019, accepted on 7 October 2019. 
that development is influenced not only by the quantitative but also qualitative level of materials, natural and financial resources, as well as relations, connections and opportunities for using the resources, which are unique for the specific region and to a great degree depend on the human capital and social capital. Additionally, the growing importance of an innovative environment and knowledge based economy constitute the incentives to search for an answer to the question as to the conditions which should be met for optimum diffusion of knowledge and innovation in a specific region. One of the conditions is the presence of a network of connections, norms and values allowing for cooperation based on trust and reputation, which as a result leads to exchange of knowledge and information. Therefore, the role of social capital, understood as "all networks which share norms, values and understanding allowing for cooperation within groups and among them" [Grabowska-Powaga, 2019, p. 111] increased.

Therefore, it is justified to claim that the quality and intensity of cooperation in a given region depends on the level of social capital, however it may both stimulate local development or constitute its material obstacle. On the on hand, strong and long-term connections integrate each social group, however, they may impede the process of moving outside of the group and opening up to other communities. Furthermore, researchers tried to identify which factors determine the saturation with social capital. Ethnic diversity was one of the issues analysed. In the subject literature there is a prevailing opinion that a negative correlation exists between ethnic diversity and social capital [Opioła, 2019, p. 53]. According to Putnam [2007, pp. 137-174], increased ethnic diversity leads to a fall in trust both amongst social groups and also within them. However, the negative impact of ethnic diversity reduces with the duration of the existence of such ethnically diversified communities. It should be also noted that conclusions from research on the social capital are not clear-cut with respect to that issue. Using the example of the United Kingdom, Laurence [2011, pp. 70-89] observes that while ethnic diversity reduces social trust, in general it leads to an increased cooperation among ethnic groups, and it also contributes to better perception of other groups. However, diversification of any community is a challenge for shaping social capital, which should be supported on the basis of a targeted, planned and long-term activity [Abłażewicz-Górnicka, 2012, p. 18]. Therefore, it is justified to study social capital in ethnically diversified regions, and the Podlaskie voivodeship belongs to that group.

Taking into consideration the above, the purpose of this article is to identify the level of social capital in the Podlaskie voivodeship in the local perspective (of powiats) respecting the division into multi and single-ethnic units. According to the hypothesis of this article, the level of social capital in the Podlaskie voivodeship is higher in multi-ethnic powiats. To verify this hypothesis, quantitative and comparative analyses shall be carried out including selected indicators, according to the availability of data and the volume of this article. The source of the information is data from Central Statistical Office (Local Data Bank) and the National Electoral Commission. 


\section{Social capital and the local and regional development}

The origin of the term "social capital" is related to the activities of L.H. Hanifan, a teacher from Charleston, who searched for methods to mobilise local communities to raise the level of education. The term "social capital" was used for the first time in that context in 1916, however, it should be stressed that it was introduced to sociology and economy in the second half of the $20^{\text {th }}$ century by a few researchers conducting independent studies [Sztompka, 2016, p. 286]. Scientific sources of the concept of social capital should be related to the issue of urban planning studies [Jacobs, 1961, p. 138]. Two decades later, Bordieu [1986, pp. 241-258] conducted one of the first sociological research undertakings in that field, where he stressed the role of intentional, instrumental development of relationship networks to obtain personal gains [Sztompka, 2016, p. 287]. Further research was conducted by Coleman [1988, pp. 95-120] who stated that a social group which stands out due to its trust and credibility is capable of higher productivity than a comparable group deprived of such qualities. The research conducted by Putnam on the public administration in Italy (in the context of opposition between the rich north and poor south) were of key importance for the development of the social capital theory; they led to the introduction of a definition relating the efficiency of achieving the social targets with networks, norms and trust [Putnam, 1993, p. 167]. The significance of trust was also stressed by Fukuyama [1995] who observed the power of collectivity in social capital, at the same time stressing the role of collective values of whole nations or communities. Another interesting study was conducted by Richman [2006, pp. 383-420] on the New York community of diamond merchants; he noticed the significance of rational endeavours to establish reputation to assure the participation in potential transactional profits. While first publications on social capital were mainly written by sociologists, nowadays it is also a phenomenon discussed by specialists in management, as well as economy. Social capital is subject to studies related to development [Woolcock, 1998, pp. 151-208] and innovation [Fountain, 1998, pp. 103-115; Cooke, Wills, 1999, pp. 219-234]. Innovative development of a region is impossible without an adequate saturation with social capital, since innovative environment and knowledge based economy are characteristic for regions which have rich social capital resources [Malecki, 2011, pp. 10231039]. Generally, it may be stated that innovation shows strong interdependence with the level of social capital, which allows for cooperation and information exchange [Cooke, et al., 2005, p. 1074]. The importance of social capital is therefore considered in the context of conditioning for regional development as one of elements determining the level of endogenous (internal) factors.

As a result, social capital constitutes a collection of developmental factors selected according to the type criteria, in addition to other types of capital such as material, financial or human, as well as technical innovations or an external flow of people, goods and capital. However, a separate analysis of specific groups does not allow us to identify any specific aspect in the development process, which is interaction between such factors. Therefore, it is justified to include social capital, 
which constitutes the missing element of the development process analysis [yer et al., 2005, p. 1016]. However, the research on the impact of social capital on the regional development is a relatively new phenomenon in the subject literature, and the first analyses in that field were commenced in the 1990s by the OECD together with the LEED programme [Mickiewicz et all., 2016, p. 114]. It should be noted that the local social capital results from local conditioning and is specific for each territorial unit, similarly to all developmental factors of endogenous character. Social capital in the context of internal developmental resources refers to local conditions and may be defined in the following ways [Brol, 2008, p. 317]:

1. Permanently formed social order, which results from specific values, norms and attitudes shaping local social interactions.

2. Permanent and institutionalised network of relations, friendships, trust and mutual acknowledgement (local government and business self-government institutions, local unions, associations, civic society organisations, etc.).

3. Social interactions (within the local community, inside institutions and organisations, as well as between both groups), which are the source of values consolidating the local community.

Social capital may be also treated as an element of institutional order in the region. According to D. North, institutions are "the rules of the game in society or more formally they are the humanly devised constraints that shape human interactions" [North, 1990, p. 3]. If we accept the division of institutions into formal and informal, then social capital should be classified as the latter. Within informal institutions, similarly to formal institutions, we can introduce a division into "efficient" and "redistributive" institutions. In the first group, we have social trust, social capital or standards of public services, while the other group includes neocorporatonism, lobbing or clientelism [Rothstein, 2012].

The division introduced by Putnam [2008, p. 41] into the exclusive capital (bonding) and inclusive (bridging) capital may supplement the considerations concerning the influence of social capital on the local and regional development. Social groups of the former type are focused on cooperation and external contacts, while in social groups of the latter type the contact network is dense but the social groups are closed to people from the outside. It should be stated that a great saturation with the bonding capital may have a negative impact on the development, while the bridging capital may contribute to the economic development in situations where we can distinguish many social sub-groups. In fact, links between specific social groups are not as strong as those within specific groups, but they are an opportunity to go outside one's own environment which in turn extends the scope of information and knowledge [Granovetter, 1973, pp. 1360-1380]. If we transfer the division of social capital to Polish regions, it can be noticed that in western regions bonding social capital exists, while bridging social capital dominates the eastern regions with the exception of the Warminsko-Mazurskie voivodeship, where the bonding social capital dominates [Swianiewicz et al., 2010, pp. 41-42]. 


\section{Social capital in the Podlaskie voivodeship. Selected indicators}

The Podlaskie Voivodeship is located in north-eastern Poland and covers an area of $20,187 \mathrm{~km}^{2}$. Its population amounts to ca. 1,190,000 people, 298,000 of whom live in Białystok, the capital of the voivodeship. The modern Podlaskie Voivodeship comprises several historical regions. The western part (powiats of Grajewo, Kolno, Łomża, Wysokie Mazowieckie and Zambrów) belongs to Mazovia. Three nothern regions (of Augustów, Sejny and Suwałki) are part of the Post-Yotvingian Suwałki region, the eastern part of the Siemiatycze powiat belongs to Polesie, and the proper Podlasie includes powiats of Sokółka, Mońki, Białystok, Bielsk Podlaski, Siemiatycze and Hajnówka. Additionally, in the Podlaskie Voivodeship there are followers of the Polish Autocephalous Orthodox Church, but it should be stressed that the majority of them identify themselves as Polish nationals. An additional element of the diversified image of the Podlaskie Voivodeship are the national minorities belonging to the Belarusian, Lithuanian, Tatars, Old Believers and others.

\section{Ethnic diversification of the Podlaskie Voivodeship}

Municipalities, where the total share of people who declared in the first or second question other than Polish national-ethnic identity amounted to at least $10 \%$.

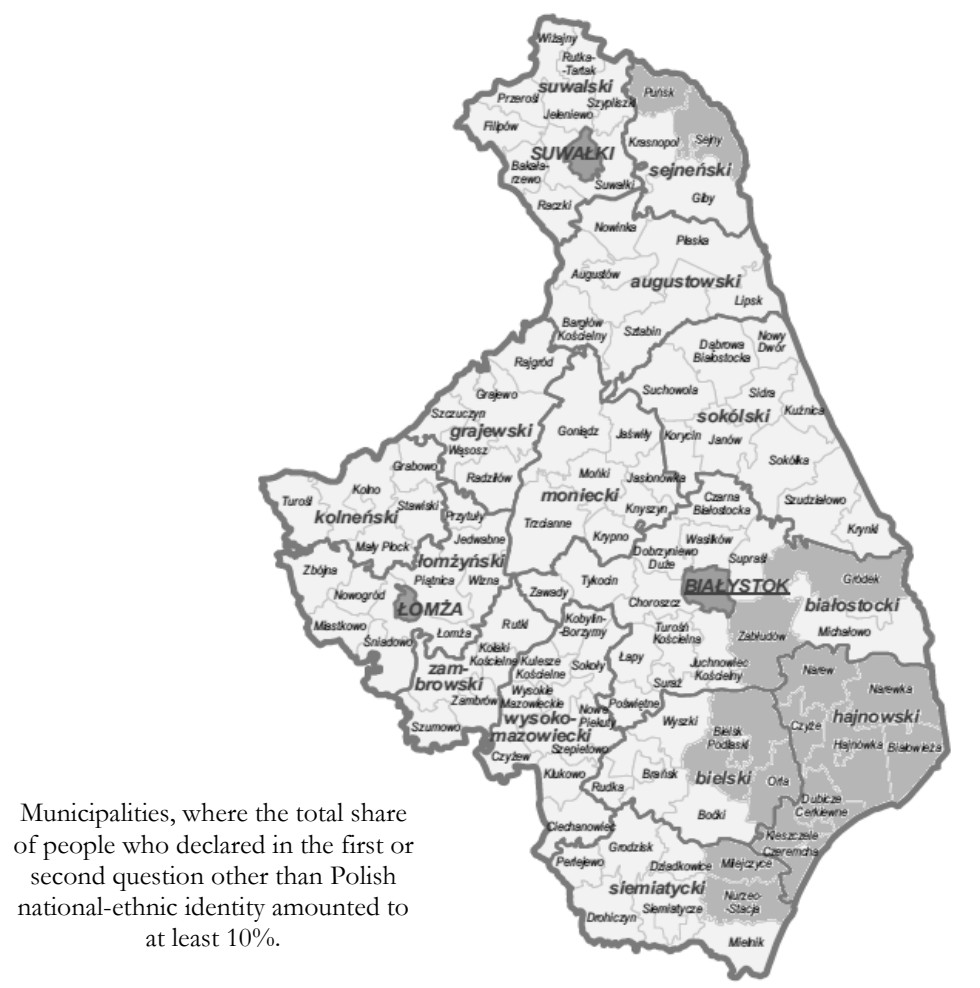

CHART 1

Source: own elaboration on the basis: [Struktura narodowo-etniczna ..., 2015]. 
In 2011, in the Podlaskie Voivodeship, 51,000 people declared nationality other than Polish, which corresponded to $4.3 \%$ of all inhabitants of the region [Struktura narodowo-etniczna..., 2015, p. 42]. In 18 out of 118 municipalities (gminas) in the Podlaskie Voivodeship, a level of $10 \%$ of national identification other than Polish was exceeded (chart 1), i.e. in 2 urban gminas Bielsk Podlaski and Hajnówka; in 2 urban-rural gminas: Kleszczele, Zabłudów, and in 14 rural gminas.

On the level of powiats, national-ethnic identification other than Polish exceeded a level of $20 \%$ in the case of powiats of Bielsk Podlaski (mainly the Belarusian minority) and Sejny (Lithuanian minority), and 30\% in the powiat of Hajnówka (mainly the Belarusian minority) [Struktura narodowo-etniczna... 2015, p. 46]. As a result, one should classify the powiats of Hajnówka, Bielsk Podlaski and Sejny as multi-ethnic. The remaining powiats belong to the single-ethnic powiats. Such division was adopted for the purpose of the analysis of social capital in the Podlaskie voivodeship.

TABLE 1

Selected social capital indicators

\begin{tabular}{|c|l|l|l|}
\hline Quality & \multicolumn{1}{|c|}{ Entrepreneurship } & \multicolumn{1}{c|}{$\begin{array}{c}\text { Active } \\
\text { organisations }\end{array}$} & \multicolumn{1}{c|}{ Social activity } \\
\hline \multirow{5}{*}{ Indicators } & $\begin{array}{l}\text { Business units per } \\
1,000 \text { inhabitants at } \\
\text { production age }\end{array}$ & $\begin{array}{l}\text { Foundations, } \\
\text { associations and } \\
\text { organsations per } \\
1,000 \text { inhabitants }\end{array}$ & $\begin{array}{l}\text { No. of candidates to } \\
\text { powiat council per } \\
1 \text { mandate in local } \\
\text { government elections }\end{array}$ \\
\cline { 2 - 5 } & & $\begin{array}{l}\text { So. of candidates to } \\
\text { powiat council per } \\
10,000 \text { inhabitants } \\
\text { in local government } \\
\text { elections }\end{array}$ \\
\cline { 2 - 5 } & & $\begin{array}{l}\text { Voters turnout in } \\
\text { local government } \\
\text { elections }\end{array}$ \\
\hline
\end{tabular}

Source: own elaboration.

Any attempt to measure social capital poses methodological challenges, primarily due to the multiplicity of aspects and the complexity of this concept. First of all, as a concept which combines both issues from economics and sociology, it requires both fields to be included. Secondly, comparability of research results among territorial units is not always possible due to local conditions. Thirdly, elements of social capital, such as trust or truthfulness are difficult to measure, therefore it is necessary to carry out intermediate research with the use of indicators expressing its existence. According to Putnam, such indicators include membership of voluntary groups or voter turnout [Sierocińska, 2011, p. 76]. If we accept the division of social capital into inclusive and exclusive, the first type is represented by indicators describing the quality of relationships in a given group (e.g. a family), and in the second case social 
capital should be measured for example, with the number of associations, citizen awareness and political participation [Sabatini, 2006, pp. 41-43]. Taking into consideration aspects of regional development, special attention should be focused on such elements as the level of entrepreneurship, NGO's and social activity [Churski, 2008, p. 68]. Therefore, an analysis of a group of indictors (table 1) was conducted, which concern the aforementioned aspects of exclusive social capital, although the border between both groups is not clear and the same indicators when treated as inclusive may be treated as "totally opposite as examples of the presence of exclusive social capital" [Sierocińska, 2011, p. 79], depending on the adopted purpose of the study.

TABLE 2

Level of entrepreneurship and number of foundations, associations and social organizations in the Podlaskie voivodeship from 2010 to 2018

\begin{tabular}{|c|c|c|c|c|c|c|c|c|c|c|}
\hline \multirow[t]{2}{*}{ Powiats } & \multicolumn{5}{|c|}{$\begin{array}{c}\text { Business units per } 1,000 \\
\text { inhabitants at production age }\end{array}$} & \multicolumn{5}{|c|}{$\begin{array}{l}\text { Foundations, associations } \\
\text { and organsations per } 1,000 \\
\text { inhabitants }\end{array}$} \\
\hline & 2010 & 2012 & 2014 & 2016 & 2018 & 2010 & 2012 & 2014 & 2016 & 2018 \\
\hline Augustów & 110 & 112 & 116 & 115 & 120 & 2.53 & 2.69 & 3.00 & 3.16 & 3.12 \\
\hline Białystok & 114 & 121 & 131 & 136 & 147 & 2.20 & 2.35 & 2.62 & 2.86 & 3.06 \\
\hline Bielsk Pod & 103 & 108 & 111 & 115 & 122 & 2.10 & 2.36 & 2.55 & 2.84 & 2.93 \\
\hline Grajewo & 93 & 94 & 98 & 101 & 105 & 2.19 & 2.48 & 2.67 & 2.87 & 3.03 \\
\hline Hajnówka & 104 & 107 & 112 & 114 & 118 & 2.78 & 3.26 & 3.56 & 3.71 & 3.99 \\
\hline Kolno & 91 & 94 & 99 & 98 & 100 & 2.22 & 2.18 & 2.44 & 2.59 & 2.63 \\
\hline Łomża & 87 & 89 & 94 & 93 & 99 & 2.78 & 2.88 & 3.10 & 3.24 & 2.96 \\
\hline Mońki & 84 & 86 & 88 & 92 & 99 & 2.23 & 2.43 & 2.65 & 2.79 & 2.78 \\
\hline Sejny & 92 & 90 & 98 & 100 & 106 & 3.16 & 3.43 & 3.66 & 4.11 & 4.18 \\
\hline Siemiatycze & 88 & 89 & 93 & 99 & 104 & 2.47 & 2.91 & 3.23 & 3.38 & 3.45 \\
\hline Sokółka & 83 & 85 & 89 & 92 & 96 & 2.57 & 2.74 & 3.04 & 3.31 & 3.48 \\
\hline Suwałki & 78 & 81 & 86 & 88 & 94 & 2.21 & 2.39 & 2.78 & 2.98 & 3.19 \\
\hline Wysokie Mazowieckie & 104 & 108 & 113 & 115 & 118 & 2.51 & 2.74 & 2.99 & 3.21 & 3.13 \\
\hline Zambrów & 114 & 116 & 116 & 118 & 125 & 1.70 & 1.83 & 2.02 & 2.20 & 2.01 \\
\hline Białystok city & 160 & 168 & 177 & 186 & 198 & 3.22 & 3.54 & 4.02 & 4.41 & 4.37 \\
\hline Łomża city & 144 & 146 & 153 & 157 & 163 & 2.72 & 2.90 & 3.12 & 3.36 & 3.21 \\
\hline Suwałki city & 152 & 151 & 153 & 154 & 159 & 2.60 & 2.90 & 3.12 & 3.43 & 3.16 \\
\hline
\end{tabular}

Source: own elaboration on the basis: [Podmioty gospodarki..., GUS].

The research was conducted on the level of powiats. To conduct comparative analysis of ethnically homogenous and diversified powiats, it is justified to exclude cities with powiat status (Białystok, Łomża, Suwałki), since their inclusion could disturb the comparative picture. Therefore, further analysis shall include only the 
land powiats (however, data concerning cities with powiat status have been also included in the tables for information).

One of the selected aspects of studying the social capital is the measurement of the entrepreneurship level in which case the indicator assessed the number of business units per 1,000 inhabitants at the production age (table 2). In 2018, the indicator ranged from 94 business units in the Suwałki powiat to 145 units in the Białystok powiat. The average coefficient value for single-ethnic land powiats amounted to 110 units, and in the case of multi-ethnic land powiats, it amounted to 115 units. It should be noticed that multi-ethnic powiats were homogenous with respect to the studied indicator which is evidenced with the value of the coefficient of variation which amounted to $6 \%$, which is statistically insignificant. On the other hand, the single-ethnic powiats were more diversified, and the value of the coefficient of variation amounted to $14 \%$. Generally, it may be stated that the level of entrepreneurship in ethnically diversified powiats was higher than in other powiats of the voivodeship and they were homogenous with respect to the level of the studied indicator.Taking into consideration the indicator expressing the number of foundations, associations and social organisations per 1,000 inhabitants (table 2); it ranged from 2 units in the Zambrów powiat to 4.2 in the Sejny powiat. In the ethnically homogenous powiats, the average value of the indicator amounted to 3.7 (the average value for all land powiats amounted to 3.1). As a result, it may be stated that that in multi-ethnic powiats the number of foundations, associations and social organisations is significantly higher than in other powiats of the voivodeship.

An important aspect of social capital is the willingness of inhabitants to voluntarily spend their leisure time, which is manifested for example by membership of sports clubs (table 3). Therefore, two indicators have been identified, i.e. the number of sport clubs per 10,000 inhabitants and the number of members of sports clubs per 10,000 inhabitants. In 2018, the first indicator ranged from 1.8 clubs in the Łomża powiat to 5.2 clubs in the Sokółka powiat. The average value of the indicator for all analysed powiats amounted to 3.5 clubs, however among multi-ethnic powiats it was lower $(2.7$ clubs), but it was characterised with a lower coefficient of variation of the analysed indicator (19\% in comparison to $28 \%$ in the case of single-ethnic powiats).

Similarly to the indicator referring to membership of sports clubs per 10,000 inhabitants, the average value of the indicator for single-ethnic powiats was much higher (223.2 persons) than in multi-ethnic powiats (144.9 persons). The second group was also characterised with a lower coefficient of variation (15\% in comparison to $25 \%$ in the first group). 
TABLE 3

\section{Sport clubs and their membership in the Podlaskie voivodeship from 2010 to 2018}

\begin{tabular}{|c|c|c|c|c|c|c|c|c|c|c|}
\hline \multirow[t]{2}{*}{ Powiats } & \multicolumn{5}{|c|}{$\begin{array}{l}\text { Sport clubs per } 10,000 \\
\text { inhabitants }\end{array}$} & \multicolumn{5}{|c|}{\begin{tabular}{|c|}
$\begin{array}{c}\text { No. of members in sport clubs } \\
\text { per } 10,000 \text { inhabitants }\end{array}$ \\
\end{tabular}} \\
\hline & 2010 & 2012 & 2014 & 2016 & 2018 & 2010 & 2012 & 2014 & 2016 & 2018 \\
\hline Augustów & 4.3 & 4.3 & 3.9 & 3.9 & 4.6 & 202.2 & 189.6 & 165.1 & 204.1 & 244.5 \\
\hline Białystok & 3.7 & 3.3 & 3.7 & 3.9 & 4.0 & 239.7 & 176.0 & 218.0 & 190.6 & 246.0 \\
\hline Bielsk Pod & 3.7 & 3.1 & 2.8 & 2.3 & 3.1 & 206.4 & 177.1 & 149.4 & 105.2 & 138.0 \\
\hline Grajewo & 5.0 & 5.3 & 5.6 & 4.6 & 4.6 & 307.4 & 307.0 & 332.6 & 293.7 & 289.2 \\
\hline Hajnówka & 3.2 & 3.5 & 3.8 & 2.7 & 3.0 & 171.7 & 141.4 & 142.4 & 98.3 & 173.8 \\
\hline Kolno & 3.5 & 3. & 3.0 & 3.3 & 2.6 & 152.6 & 159.8 & 109.0 & 158.0 & 129.4 \\
\hline Łomża & 3.8 & 3.8 & 3.3 & 2.9 & 1.8 & 147.0 & 164.3 & 136.4 & 413.4 & 102.5 \\
\hline Mońki & 3.3 & 3.5 & 2.4 & 2.7 & 2.5 & 165.5 & 203.6 & 142.0 & 169.9 & 249.3 \\
\hline Sejny & 4.7 & 3.8 & 3.9 & 2.0 & 2.0 & 221.0 & 335.4 & 221.4 & 157.2 & 122.9 \\
\hline Siemiatycze & 4.1 & 4.9 & 4.3 & 4.4 & 4.5 & 228.5 & 246.4 & 228.9 & 202.5 & 241.9 \\
\hline Sokółka & 4.8 & 4.4 & 4.6 & 5.1 & 5.2 & 207.5 & 188.4 & 186.3 & 231.6 & 256.4 \\
\hline Suwałki & 4.4 & 3.9 & 3.9 & 4.2 & 4.2 & 193.3 & 176.8 & 195.1 & 252.2 & 240.3 \\
\hline Wysokie Mazowieckie & 3.7 & 4.1 & 3.9 & 4.0 & 3.7 & 189.4 & 203.7 & 210.0 & 201.7 & 194.8 \\
\hline Zambrów & 3.5 & 3.1 & 3.1 & 3.2 & 3.2 & 227.7 & 186.3 & 178.6 & 282.9 & 260.6 \\
\hline Białystok city & 3.0 & 3.1 & 3.6 & 3.7 & 4.1 & 278.9 & 299.1 & 310.8 & 341.9 & 409.3 \\
\hline Łomża city & 4.3 & 4.6 & 4.0 & 5.1 & 4.9 & 313.9 & 329.1 & 305.2 & 363.0 & 404.9 \\
\hline Suwałki city & 2.6 & 2.7 & 3.3 & 3.3 & 4.2 & 258.4 & 260.1 & 304.0 & 274.6 & 325.1 \\
\hline
\end{tabular}

Source: own elaboration on the basis: [Kultura fizyczna..., GUS].

The civic dimension of social capital is represented by indicators referring to passive and active voting right in local government elections. The passive voting right has been described with the use of two indicators, i.e. the number of candidates per one mandate in the powiat council and the number of candidates per 1,000 persons entitled to vote. Taking into consideration the first indicator (table 4), in 2018 it ranged from 4.9 candidates in the Grajewo powiat to 7.9 candidates in the Sokółka powiat. The average value of the indicator for all powiats amounted to 6.3 candidates, and for multi-ethnic powiats it was slightly higher than in single-ethnic powiats (respectively 6.7 and 6.2).

With respect to the second indicator describing the passive voting right, the number of candidates per 1,000 entitled to vote (table 5) ranged from 1.75 candidates in the Białystok powiat to 6.15 candidates in the Sejny powiat. In the case of the second indicator, the advantage of powiats ethnically diversified was considerable, which is expressed by a higher average value (3.8 candidates) than in singleethnic (2.5 candidates). 
TABLE 4

\section{Candidates per 1 mandate in elections to powiat councils in the Podlaskie voivodeship in 2010, 2014 and 2018}

\begin{tabular}{|l|c|c|c|c|c|c|c|c|c|}
\hline \multirow{2}{*}{ Powiats } & \multicolumn{3}{|c|}{ Candidates } & \multicolumn{3}{c|}{ No. of mandates } & \multicolumn{3}{c|}{$\begin{array}{c}\text { No. of candidates } \\
\text { per 1 mandate }\end{array}$} \\
\cline { 2 - 13 } & $\mathbf{2 0 1 0}$ & $\mathbf{2 0 1 4}$ & $\mathbf{2 0 1 8}$ & $\mathbf{2 0 1 0}$ & $\mathbf{2 0 1 4}$ & $\mathbf{2 0 1 8}$ & $\mathbf{2 0 1 0}$ & $\mathbf{2 0 1 4}$ & $\mathbf{2 0 1 8}$ \\
\hline Augustów & 191 & 149 & 115 & 19 & 17 & 17 & 10.1 & 8.8 & 6.8 \\
\hline Białystok & 168 & 261 & 204 & 25 & 27 & 27 & 6.7 & 9.7 & 7.6 \\
\hline Bielsk Podlaski & 164 & 186 & 110 & 19 & 17 & 17 & 8.6 & 10.9 & 6.5 \\
\hline Grajewo & 111 & 103 & 83 & 17 & 17 & 17 & 6.5 & 6.1 & 4.9 \\
\hline Hajnówka & 111 & 126 & 113 & 17 & 17 & 17 & 6.5 & 7.4 & 6.6 \\
\hline Kolno & 221 & 106 & 92 & 17 & 17 & 15 & 13.0 & 6.2 & 6.1 \\
\hline Lomża & 147 & 158 & 116 & 17 & 17 & 17 & 8.6 & 9.3 & 6.8 \\
\hline Mońki & 136 & 222 & 120 & 17 & 17 & 17 & 8.0 & 13.1 & 7.1 \\
\hline Sejny & 130 & 200 & 106 & 15 & 15 & 15 & 8.7 & 13.3 & 7.1 \\
\hline Siemiatycze & 142 & 167 & 97 & 17 & 17 & 17 & 8.4 & 9.8 & 5.7 \\
\hline Sokółka & 128 & 190 & 150 & 19 & 19 & 19 & 6.7 & 10.0 & 7.9 \\
\hline Suwałki & 117 & 105 & 76 & 15 & 15 & 15 & 7.8 & 7.0 & 5.1 \\
\hline Wysokie Mazowieckie & 130 & 101 & 108 & 19 & 17 & 17 & 6.8 & 5.9 & 6.4 \\
\hline Zambrów & 141 & 113 & 69 & 17 & 17 & 17 & 8.3 & 6.6 & 4.1 \\
\hline Białystok city & 255 & 386 & 202 & 28 & 28 & 28 & 9.1 & 13.8 & 7.2 \\
\hline Lomża city & 254 & 294 & 206 & 23 & 23 & 23 & 11.0 & 12.8 & 9.0 \\
\hline Suwałki city & 260 & 285 & 178 & 23 & 23 & 23 & 11.3 & 12.4 & 7.7 \\
\hline
\end{tabular}

Source: own elaboration on the basis: [www: 1, 2, 3].

Analysis of an active voting right was carried out with the use of voters' turnout in the local government elections (table 5). In 2018, the voters' turnout was the highest in the Suwałki powiat (57.21\%), and the lowest in the Augustów powiat $(48.89 \%)$. In the whole voivodeship, the lowest number of inhabitants entitled to vote actually voted in the city of Suwałki (46.87\%) which is not included in the analysis. When comparing single-ethnic and multi-ethnic powiats, it is not possible to notice outstanding differences in the turnout, which in 13 out of 17 powiats (land powiats and cities with a powiat status) was lower than the average national turnout $(54.90 \%)$. 
TABLE 5

No. of candidates per 1,000 entitled to vote and voters turnout in elections for powiat councils in the Podlaskie voivodeship in 2010, 2014 and 2018

\begin{tabular}{|c|c|c|c|c|c|c|c|c|c|}
\hline \multirow[t]{2}{*}{ Powiats } & \multicolumn{3}{|c|}{$\begin{array}{l}\text { No. of inhabitants } \\
\text { entitled to vote }\end{array}$} & \multicolumn{3}{|c|}{$\begin{array}{c}\text { Candidates } \\
\text { per } 1,000 \\
\text { of inhabitants } \\
\text { entitled to vote }\end{array}$} & \multicolumn{3}{|c|}{ Voters turnout (\%) } \\
\hline & 2010 & 2014 & 2018 & 2010 & 2014 & 2018 & 2010 & 2014 & 2018 \\
\hline Augustów & 47978 & 47851 & 46824 & 3.34 & 3.11 & 2.40 & 45.36 & 49.04 & 48.89 \\
\hline Białystok & 113084 & 116440 & 118016 & 1.15 & 2.31 & 1.75 & 49.31 & 51.43 & 55.76 \\
\hline Bielsk Pod & 49363 & 48432 & 46334 & 2.94 & 3.77 & 2.27 & 51.54 & 52.26 & 55.18 \\
\hline Grajewo & 39872 & 39596 & 38481 & 2.34 & 2.58 & 2.10 & 51.24 & 52.53 & 51.76 \\
\hline Hajnówka & 40737 & 39045 & 37112 & 2.56 & 3.09 & 2.89 & 53.95 & 48.79 & 54.14 \\
\hline Kolno & 31936 & 31864 & 31258 & 5.72 & 3.32 & 2.89 & 54.35 & 53.92 & 53.43 \\
\hline Lomża & 41102 & 41765 & 41431 & 2.85 & 3.84 & 2.78 & 54.2 & 53.81 & 55.52 \\
\hline Mońki & 35201 & 34821 & 34039 & 3.32 & 6.31 & 3.45 & 50.02 & 48.79 & 50.16 \\
\hline Sejny & 17282 & 17222 & 16799 & 6.39 & 11.57 & 6.15 & 51.79 & 55.6 & 52.10 \\
\hline Siemiatycze & 40133 & 39493 & 38129 & 3.11 & 4.16 & 2.46 & 51.65 & 51.4 & 52.58 \\
\hline Sokółka & 59430 & 58470 & 56250 & 1.88 & 3.20 & 2.57 & 52.34 & 51.94 & 53.08 \\
\hline Suwałki & 28727 & 29402 & 29281 & 3.19 & 3.66 & 2.58 & 52.8 & 53.43 & 57.21 \\
\hline Wysokie Mazowieckie & 48397 & 48041 & 47030 & 2.24 & 2.09 & 2.25 & 54.1 & 53.86 & 54.66 \\
\hline Zambrów & 36106 & 35939 & \begin{tabular}{|l|}
35467 \\
\end{tabular} & 3.25 & 3.13 & 1.92 & 49.3 & 49.98 & 53.26 \\
\hline Białystok city & 228515 & 227738 & 222680 & 0.93 & 1.69 & 0.89 & 41.72 & 41.45 & 53.47 \\
\hline Lomża city & 50076 & 49590 & 48681 & 4.29 & 5.87 & 4.15 & 41.48 & 39.82 & 49.27 \\
\hline Suwałki city & 54260 & 54379 & 53960 & 3.88 & 5.25 & 3.27 & 41.04 & 40.5 & 46.87 \\
\hline
\end{tabular}

Source: own elaboration on the basis: [www: 1, 2, 3].

Recapitulating, with reference to the passive and active voting right it may be observed that there are significant differences between single-ethnic powiats and multi-ethnic powiats. While the voters' turnout in both identified groups is similar, the passive voters' right is to a greater degree used in multi-ethnic powiats, which is clearly evidenced with the number of candidates to powiat councils per one mandate.

\section{Conclusions}

In the subject literature there is a dominating opinion that the Podlaskie voivodeship is a region characterised with inclusive social capital. It shows strong internal relations in specific social groups, which on the one hand may contribute to the sense of safety and stabilisation, but on the other hand it can be a significant barrier to local development. It results first of all from the assumption that local development, in particular of an innovative nature, requires knowledge and 
information flow, which in turn results from opening up to other environments and social groups. This feature, on the other hand, is characteristic for regions of high exclusive saturation with social capital. Although the border between the indicators of inclusive and exclusive social capital is not sharp, nevertheless it should be noticed that when considering social capital from the perspective of local development the exclusive social capital is of cardinal importance. It is described by, for example, social activity, levels of entrepreneurship, civic consciousness and social participation. Indicators referring to such aspects of social capital were included in this article.

According to the analysis of selected indicators it may be stated that in the case of the Podlaskie voivodeship, the level of social capital is higher in powiats which are more ethnically diverse. Among the analysed indicators, only in the case of one of them a slight advantage of single-ethnic powiats can be observed, i.e. with respect to the number of sport clubs and their membership per 10,000 inhabitants. In the case of other indicators, their value is higher in multi-ethnic powiats, while in the case of the indicator describing the level of entrepreneurship the advantage is minor. The remaining analysed aspects of social capital are the evidence of its much higher level in multi-ethnic powiats, in which the number of organisations and associations per 1,000 inhabitants is $24 \%$ higher than in single-ethnic powiats. Similarly, the civic aspect of social capital is more intensive in multi-ethnic powiats, which is evidenced by a $8 \%$ higher number of candidates to powiat councils per 10,000 inhabitants, and first of all by number of candidates to powiat councils per 1 mandate, which is higher by $50 \%$. As a result, the research hypothesis adopted for this article that in the Podlaskie voivodeship the potential of social capital is higher in multi-ethnic powiats has been verified positively. However, taking into consideration the character of social and economic processes, i.e. their dynamics, it should be stated that the assessment of social capital requires further analyses, including thorough quantitative and qualitative studies.

It should be stated that the cause-and-effect relations were not subject to the analysis of this paper. Due to the potential impact of other factors, according to the presented data it is difficult to state clearly whether the ethnic diversity is the source of higher social capital. Furthermore, it would be necessary to conduct qualitative studies to make a clear thesis about a positive impact of ethnic diversity (e.g. in a form of a questionnaires referring to trust, reputation, perception of social groups, etc.). However, it may be stated that in multi-ethnic powiats in the Podlaskie voivodeship, ethnic diversity is not a factor reducing the level of social capital, which is evidenced by the analysis of selected factors.

A statement made by Putnam may explain the aforementioned observations, namely that the ethnic diversity has an adverse impact on social capital only in the initial period, while in the case of the Podlaskie voivodeship the presence of the Belarusian and Lithuanian minority has a tradition of many centuries. Furthermore, representatives of ethnic minorities may be counted as indigenous people rather than new-comers. Therefore the thesis presented by J. Laurenc that social diversity in general contributes to increased cooperation appears to be correct, and the 
example of the Podlaskie voivodeship may serve as an evidence of that. Additionally, a conclusion may be drawn that multi-ethnic powiats are more homogenous with respect to the discussed indicators, although geographically they belong to different areas of the Podlaskie voivodeship.

\section{References}

Abłażewicz-Górnicka U., 2012, Zróżnicowanie etniczno-kulturowe a kapitał społeczny. Gtos w debacie o wielokulturowości, „Pogranicze. Studia Społeczne”, t. XX, s. 7-20, DOI: 10.15290/pss.2012.20.01.

Bordieu P., 1986, The Forms of Capital, [in:] Handbook of Theory and Research for the Sociology of Education, Richardson J.G. (ed.), Greenwood Press, New York.

Brol R., 2008, Kapitat spoteczny w gospodarce lokalnej, [w:] Gospodarka lokalna i regionalna w teorii i praktyce, Brol R. (red.), Wydawnictwo Uniwersytetu Ekonomicznego we Wrocławiu, Wrocław.

Churski P., 2008, C乏ynniki rozwoju regionalnego i polityka regionalna w Polsce w okresie integraci z. Unia Europejska, Wydawnictwo UAM, Poznań.

Coleman J.S., 1988, Social capital in the creation of human capital, "American Journal of Sociology", vol. 94, pp. 95-120.

Cooke P., Clifton N., Oleaga M., 2005, Social capital, firm embeddedness and regional development, "Regional Studies", vol. 39, iss. 8, pp. 1065-1077, DOI: 10.1080/ 00343400500328065.

Cooke P., Wills D., 1999, Smallfirms, social capital and the enhancement of business performance through innovation programmes, "Small Business Economics", vol. 13, iss. 3, pp. 219-234, DOI: 10.1023/A:1008178808631.

Fountain J., 1998, Social capital: its relationship to innovation in science and technology, "Science and Public Policy", vol. 25(2), pp. 103-115, DOI: 10.1093/spp/25.2.103.

Fukuyama F., 1995, Trust. The Social Virtues and the Creation of Prosperity, Free Press, New York.

Grabowska-Powaga A., 2019, Kapitat spoteczny a gospodarowanie, Wydawnictwo CeDeWu, Warszawa.

Granovetter M., 1973, The strength of weak ties, "The American Journal of Sociology", vol. 78, no. 6, pp. 1360-1380.

Iyer S., Kitson M., Toh B., 2005, Social capital, economic growth and regional development, "Regional Studies", vol. 39, iss. 8, pp. 1015-1040, DOI: 10.1080/00343400500 327943.

Jacobs J., 1961, The Death and Life of Great American Cities, Random House, New York.

Kultura fizyczna, sport i rekreacja. Grupa: Sport. Podgrupa: Kluby Sportowe, GUS, https:// bdl.stat.gov.pl/BDL/dane/podgrup/tablica [date of entry: 09.08.2019].

Laurence J., 2011, The effect of ethnic diversity and community disadvantage on social cohesion: A multi-level analysis of social capital and interethnic relations in UK communities, "European Sociological Review”, vol. 27, iss. 1, pp. 70-89, DOI: 10.1093/esr/jcp057. 
Malecki E.J., 2011, Regional Social Capital: Why it Matters, "Regional Studies", vol. 46, iss. 8, pp. 1023-1039, DOI: 10.1080/00343404.2011.607806.

Mickiewicz T., Rodzinka J., Skica T., 2016, Lokalne i regionalne czynniki wspierania przedsiebiorczości, Klasteryzacja, promocja, doradztwo i i kapitat społeczny, Wydawnictwo C.H. Beck, Warszawa.

North D.C., 1990, Institutions, Institutional Change and Economic Performance, Cambridge University Press, New York.

Opioła W., 2019, Wphyw zróżnicowania narodowościonvego na poziom kapitatu społecznego lokalnej wspólnoty. Badanie porównawcze w wybranych gminach wojewódz̧twa opolskiego, „Studia Regionalne i Lokalne”, nr 1(75), s. 52-69, DOI: 10.7366/15094995 17503.

Podmioty Gospodarki Narodowej, przeleształcenia wtasnościowe i strukturalne. Grupa: podmioty gospodarki narodowej wskaźniki. Podgrupa: Podmioty wskaźniki, GUS, https://bdl.stat. gov.pl/BDL/dane/podgrup/tablica [date of entry: 10.08.2019].

Putnam R.D., 1993, Making Democracy Work, Princeton University Press, Princeton, New York.

Putnam R.D., 2007, E pluribus unum: Diversity and community in the twenty-first-century. The 2006 Johan Skytte Prize Lecturer, "Scandinavian Political Studies", vol. 30, no. 2 , pp. 137-174, DOI: 10.1111/j.1467-9477.2007.00176.x.

Putnam R.D., 2008, Samotna gra w kregle: upadek i odrodzenie wspólnot lokalnych w Stanach Zjednoczonych, Wydawnictwo Akademickie i Profesjonalne, Warszawa.

Richmann B.D., 2006, How Community Institutions Create Economic Advantage. Jewish Diamont Merchants in New York, "Law \& Social Inquiry", vol. 31, no. 2, pp. 383420.

Rothstein B., 2009, Preventing markets form Self-Destruction: The Quality of Government Factor, QoG Working Papers Series, Goteborg.

Sabatini F., 2006, Does Social Capital Improve Labour Productivity in Small and Medium Enterprises?, La Sapienza, Roma.

Sierocińska K., 2011, Kapitat spoteczny. Definiowanie, pomiar i typy, "Economic studies", nr 1 (LXVIII), s. 69-86.

Struktura narodowo-etniczna, jesykowa i myznaniowa ludności Polski, Narodowy Spis Powszechny ludności i miesžkań, 2015, GUS, Warszawa.

Swianiewicz P., Krukowska J., Lackowska M., Mielczarek A., 2010, Nie-strategične zarzadzanie rozwojem? Mechanizmy zarzadzania środkami ZPORR na poziomie regionalnym a skuteczność realizacji celón rozwojonych, Ministerstwo Rozwoju Regionalnego, Warszawa.

Sztompka P., 2016, Kapitat spoleczny. Teoria przestrzeni miedżyludžkiej, Wydawnictwo Znak, Kraków.

Woolcock M., 1998, Social capital and economic development: towards a theoretical synthesis and policy framework, "Theory and Society", no. 27, pp. 151-208.

www 1, https://wybory2010.pkw.gov.pl/geo/pl/200000/200000.html\#tabs-2 [date of entry: 14.08.2019]. 
www 2, https://samorzad2014.pkw.gov.pl/343_Kandydaci/2001/1 [date of entry: 14.08.2019].

www 3, https://wybory2018.pkw.gov.pl/pl/geografia/200200\#general_committee_ stat [date of entry: 14.08.2019]. 